\title{
POR UM CAMINHO PARA O ENSINO DA EPISTEMOLOGIA NA ADMINISTRAÇÃO - UMA CONSTRUÇÃO COMPARTILHADA
}

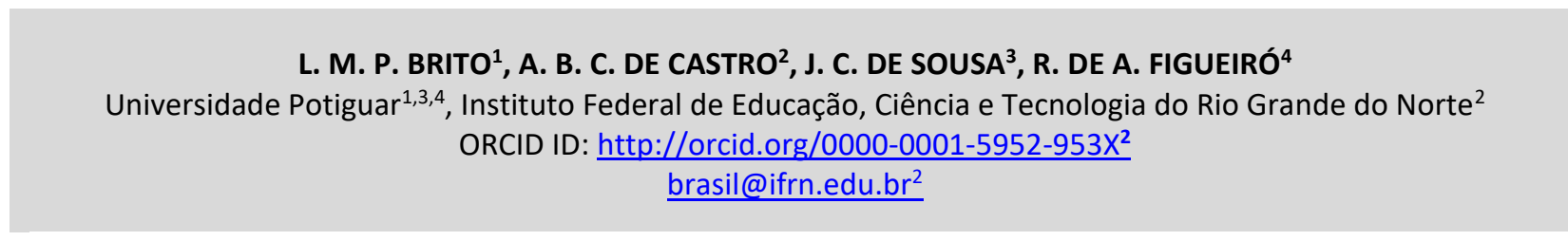 \\ Submetido em 27/12/2018 e aceito em 28/09/2020 \\ DOI: 10.15628/holos.2020.8139
}

\section{RESUMO}

O objetivo desta pesquisa foi relatar uma experiência de construção inicial da disciplina de Epistemologia de um doutorado de administração numa universidade privada do Nordeste do Brasil, a partir da conexão entre epistemologia, metodologias e textos contemporâneos de áreas do conhecimento com temáticas transversais, reconhecidos do ponto de vista acadêmico e que faziam sentido para os orientadores das teses de doutorado. 0 referencial de análise da pesquisa tem como principais menções textos da Filosofia e ciências transversais. Tratase de um estudo exploratório, em aberto, inspirado nos pressupostos da Dialética, e possui abordagem qualitativa. Configura-se como um estudo de caso, tendo como procedimentos: o diálogo, a observação participante, a pesquisa documental, a entrevista estruturada e a semiestruturada, e a análise de conteúdo. Os resultados apontaram para o enriquecimento da disciplina de Epistemologia ao longo de dois anos e o engajamento dos alunos e professores na construção de conteúdos relevantes para a disciplina. Verificou-se, no entanto, resistência de alguns professores orientadores para utilização da Filosofia da Ciência na construção das teses de doutorado dos alunos.

PALAVRAS-CHAVE: Epistemologia; Doutorado; Ensino; Administração.

\section{FOR A PATH TO TEACHING EPISTEMOLOGY IN ADMINISTRATION - A SHARED CONSTRUCTION}

\begin{abstract}
The objective of this research was to report an initial construction experience from the Epistemology subject in a doctorate class in administration in a private university in Northeastern Brazil from the connection between epistemology, methodologies and contemporary texts from knowledge areas with transversal topics, acknowledged by the academic point of view and which used to make sense to the doctor's theses advisors. The research's analysis reference's main sources are Philosophy texts and transversal sciences. This is an open-ended exploratory study inspired by the
\end{abstract}

Dialectics' suppositions with a qualitative approach and set as a case study with the following procedures: the dialogue, the attending observation, the documental research, the structured and the semi-structured interviews, and the content analysis. The results pointed out to the enrichment of the Epistemology subject over a period of two years, and the students and teachers' commitment to developing contents that are relevant to the subject. However, some advising Professors showed resistance against using Science Philosophy upon developing the students' doctoral theses.

KEYWORDS: Epistemology; Doctorate; Teaching; Administration.

HOLOS, Ano 36, v.6, e8139, 2020 


\section{INTRODUÇÃO}

O PPGAUY existe há 13 anos com a criação do Mestrado Profissional em Administração, e há quase dois com a criação do Mestrado Acadêmico em Administração. Ao fazermos o levantamento dos títulos, objetivos, lócus da pesquisa, relevância, método e principais resultados das Dissertações de mestrado produzidas e arquivadas no repositório do referido programa, no período de 2008 a 2017, em um total de 254 trabalhos, observamos a predominância de estudos "sinalizando" para os pressupostos de uma epistemologia que tem como método a lógica hipotético-dedutivo e a quantificação, e teorias com quadros de referências funcionalistas. Verificou-se que, de um modo geral, o que era considerado "método" se referia aos modos de investigação relacionados ao Polo Técnico do "como fazer", tais como: natureza da pesquisa qualitativa ou quantitativa, tipo da pesquisa com relação aos objetivos - exploratória, descritiva ou analítica, com o tipo da pesquisa com relação aos procedimentos - estudo de caso, levantamentos e outros (Bruyne, Herman \& Schoutheete, 1991). Ou seja, seguindo uma orientação própria da Administração que é essencialmente empírica / prática alinhada aos interesses do mercado e das empresas.

Entendeu-se que, "epistemologia" enquanto Filosofia da Ciência, por ser uma disciplina não muito comum nos currículos acadêmicos de graduação e pós-graduação da Administração (Van Seggelen-Damen \& Romme, 2014), "ciência aplicada" voltada para a prática organizacional / empresarial; sua construção, para ter sustentabilidade, sentido e comprometimento dos professores orientadores e doutorandos, deveria ser feita de forma compartilhada, já que estava sendo iniciada a consolidação de um "ambiente acadêmico de doutorado" favorável à construção de possibilidades de ir-se além da Administração, historicamente consolidada em sua origem na matemática / engenharia - "Administração Científica", mediante a contribuição de outras áreas do conhecimento transversais consolidadas (Morgan, 2002), como a Biologia, a Filosofia, as Ciências Sociais, a Psicologia, a Política, o Poder e a Educação.

Assim, foi considerada uma questão fundamental da Administração, que foi o fato dela utilizar prioritariamente uma razão instrumental - do como fazer técnico (Habermas, 2012), que não dá conta da complexidade da realidade, para tentar solucionar os problemas que ela mesma cria.

Desta forma, considerando que a realidade é dinâmica, complexa e contraditória e que seu entendimento crítico e construtivo passa pelas várias áreas do conhecimento, este artigo parte da seguinte questão: como descobrir, de forma compartilhada, possibilidades de Epistemologias para a Administração que favoreçam a emergência de novas teses e ações agregadoras ao conjunto da sociedade para além do conhecimento da Administração?

O estudo tem como objetivo geral relatar uma experiência de construção inicial da disciplina de Epistemologia de um doutorado de administração numa universidade privada do Nordeste do Brasil, a partir da conexão entre epistemologia, metodologias e textos contemporâneos de áreas do conhecimento com temáticas transversais, reconhecidos do ponto de vista acadêmico e que faziam sentido para os orientadores das teses de doutorado. A disciplina 
está em processo de construção e tem como principal dimensão o debate sobre opções epistêmicas e filosóficas (Serva, 2017). Tem ainda como premissa educacional básica, o entendimento de que na formação social da mente, o processo é tão importante quanto o resultado (Vygotsky, 2001). Este texto é uma primeira reflexão, dentro de todas as contradições da realidade, sobre o que está sendo construído por professores e alunos, para obtenção do comprometimento de todos com os resultados qualitativos do PPGAUY.

Esse relato se justifica por sistematizar o processo de construção da qualificação das pesquisas em administração de um novo programa de doutorado, por meio de uma ligação entre polos epistemológicos diversos numa perspectiva construtivista e relacional, que evita a hiperespecialização das ciências, para buscar a superação da hegemonia das abordagens funcionalistas nos estudos organizacionais. Além disso, o relato se justifica por revelar uma imagem original de cientificidade e como essa imagem se precisa pouco a pouco e se torna cada vez mais ativamente consciente do modo próprio de cientificidade que já começou a operar nela desde seu acionamento (Rocha, Araújo \& Marques, 2012).

\section{REFERENCIAL DE ANÁLISE}

A Epistemologia, enquanto Filosofia da Ciência estuda a origem, a natureza, a estrutura, os métodos e a validade do conhecimento. Trata o grau de certeza do conhecimento científico nas suas diferentes áreas, com o objetivo principal de estimar a sua importância para o espírito e a sociedade humana. A epistemologia tem suporte na criação e construção individual ou coletiva viabilizada pela dinâmica histórica e pela atividade discursiva (Mendoza, 2018).

A Epistemologia surgiu como oposição à crença ou opinião ao conhecimento (DANA e DUMEZ, 2015). A crença é um ponto de vista subjetivo e o conhecimento é crença verdadeira e justificada, enquanto o conjunto de todas as informações que descrevem e explicam o mundo natural e social que nos rodeia. Variadas são as taxonomias realizadas para classificar o conhecimento epistemológico (Paula, 2016; Tesch, 2013; Denzin \& Lincoln, 2011; Merriam, 1998; Burrell \& Morgan, 2017; 1979). Neste estudo, e como parte da experiência conduzida, optamos pelo entendimento da epistemologia dentro de um espaço quadripolar, conforme proposto por Bruyne et al. (1991), cujos processos discursivos, no sentido metodológico, são: Dialética, Fenomenologia, Quantificação e método Hipotético-dedutivo.

Neste acervo, a dialética pretende a captação do movimento concreto, natural e sóciohistórico, e integra em sua abordagem a própria lógica do pensamento reflexivo e científico. Assim, o método dialético só se realiza plena e vigorosamente na captação total do movimento histórico em suas contradições constituintes (Bruyne et al., 1991); e, requer uma crítica prévia do domínio estudado, do objeto e do procedimento, uma crítica das reduções e extrapolações, uma determinação do grau de coerência do objeto (Putnam, Fairhurst \& Banghart, 2016).

Já a Fenomenologia, designa o estudo dos fenômenos, isto é, aquilo que é dado a conhecer, tudo o que se manifesta, se desvela e se mostra à consciência do sujeito que o questiona. 0 fenômeno é o objeto de investigação fenomenológica que busca elucidar o seu significado. Tem como movimento realizar uma ruptura radical com as certezas positivistas que povoam a 
consciência 'ingênua' do senso comum. Trata-se do estudo da consciência e dos objetos da consciência ou também chamados de experiências de consciência ou ainda chamados de vivências. Esses objetos, experiências ou vivências podem ser caracterizados como: coisas, imagens, fantasias, atos, relações, pensamentos, eventos, memórias, sentimentos, entre outros (Surak, 2017).

Com relação à Quantificação, esta "impõe uma ordem ao universo semântico do discurso e o reduz a um universo simbólico de números. Autoriza, então, a compatibilidade numérica e a aplicação de métodos quantitativos" (Bruyne et al., 1991, p. 80). O universo simbólico é, consequentemente, reduzido a um jogo de valores possíveis, expressos sob variáveis. Esta operação, no estágio da coleta dos dados confere a cada indicador de variável um perfil sobre a escala da dimensão que se permite observar (Costa, 2011).

Enquanto que, o Método Hipotético-Dedutivo realiza uma demonstração a posteriori na qual o efeito explica (prova) a causa. Esse método, segundo Bruyne et al. (1991, p. 89):

se desenvolve na pesquisa à maneira de um ciclo, seu processo teorético-empírico é irreversível. Esquematicamente, coloca-se uma hipótese na presença de fenômenos e presume-se que ela permitirá reencontrá-los como consequências (nível das hipóteses), em seguida, outras consequências possíveis são derivadas logicamente dessa hipótese e confrontadas com os fatos disponíveis (nível da dedução).

Em um doutorado, a partir de uma epistemologia, pode-se concretizar o novo. Assim, os momentos de construção do novo seriam: teleológico, relação entre teleologia e causalidade, criação do novo e socialização do Conhecimento. O primeiro momento - Teleológico ou de PréviaIdeação, surge das necessidades decorrentes das determinações históricas, é o momento abstrato de planejamento que antecede e dirige a ação, onde o resultado é idealizado, ou seja, projetado na consciência, antes de ser construído na prática. Exerce num papel fundamental na determinação dos resultados da práxis social, pois é o momento de confronto entre passado, presente e futuro e contém em si a necessidade e possibilidade de objetivação.

No segundo momento, acontece a relação entre Teleologia e Causalidade. O trabalho é a categoria que articula em um processo de síntese o homem, portador de teleologia, e a causalidade, ambiência/situação dada pela natureza e pela sociedade. A relação entre a consciência que operou a prévia-ideação e o objeto é, ao mesmo tempo, de interdependência (sem prévia-ideação não existe objeto) e efetiva distinção, no plano do ser, entre a consciência que operou a prévia-ideação e o objeto construído. Esse segundo momento, é o momento em que o pesquisador passa a interagir com a complexidade da realidade existente nas dimensões da natureza, sociedade e ato humano.

A Objetivação é o terceiro momento, aquele que sintetiza o resultado da relação entre a teleologia e a causalidade, que potencialmente transformaria a natureza e sociedade para satisfação das necessidades humanas e produz um novo objeto. É um momento de transformação da realidade que transforma também o sujeito, embora sejam transformações diferentes. O êxito 
da objetivação deve ter como base um efetivo conhecimento do setor de realidade que se pretende transformar (Lukács, 2015).

O quarto momento é o da Criação do Novo que inicia um novo processo de produção de conhecimento. Este novo objeto, passa a ter uma função social que implica na criação de novas necessidades e novas possibilidades, e na escolha e produção de valores. É um processo de universalização imprevisível do singular, considerando que o acaso também faz parte do processo, como pontua Ferraz, Chaves e Ferraz (2018). Na dimensão ontológica do real, o acaso acontece por que o futuro não é determinado teleologicamente; o futuro é o que ainda não aconteceu (LUKÁCS, 2015).

Na Socialização do Conhecimento, é importante observar que o ser existe numa totalidade e em relação, portanto, com a totalidade. A totalidade tem as seguintes características: o objeto se insere numa malha de relações e determinações pré-existentes; o objeto construído altera a realidade em graus variados; e o objeto desencadeia nexos causais perpassados de momentos de causalidade imprevisíveis pela consciência no momento da prévia-ideação. A Socialização implica numa complexização e transformação coletiva do produto do trabalho e onde emerge o ser social (Lukács, 2015).

Finalmente, a produção de uma tese de doutorado é iniciada por uma necessidade humana e social - problema relevante, e passa por uma teleologia que se relaciona com uma causalidade para objetivação do novo, que é socializado criando novas necessidades e novas possibilidades num processo em espiral contínuo. Considerando que as teorias de Administração cada vez mais estão focadas no cliente e no mercado, em detrimento da sociedade como um todo, cabe os questionamentos que permeiam, de forma implícita, este estudo: que conhecimento está sendo produzido? Quais necessidade e possibilidades estão sendo geradas? Para quais interesses está servindo? Quais as consequências do novo para o ser social e o futuro da humanidade? As respostas podem ser buscadas através de uma vigilância epistemológica que critique o conhecimento produzido e eleve a consciência social para patamares além do saber morfológico, teórico e técnico da Administração.

\section{PERCURSO METODOLÓGICO}

O presente estudo exploratório, aberto em espiral e contendo contradições, inspirado nos pressupostos da Dialética, é de natureza qualitativa (Denzin \& Lincoln, 2011; Flick, 2004). Configura-se como um estudo de caso, relato de uma experiência que está sendo vivenciada pelos autores tendo como procedimentos: o diálogo, a observação participante (Semprebom, Freitas e Augusto, 2013), a pesquisa documental (Cellard, 2012), a entrevista estruturada (Merriam, 1998) e semiestrutura (Godoy, 1995).

Os participantes do estudo, coordenado por uma professora doutora da área de Educação com expertise em Administração, foram professores e alunos com formação predominante em Administração, da disciplina de Epistemologia da Pesquisa em Administração do PPGAUY:

1a) Turma da disciplina (2017) - 12 alunos da 1a e 2a turmas do doutorado; e, 
2a) Turma da disciplina (2018) - 6 doutorandos da 3a turma, 2 doutorandos da 2a turma que já tinham cursado a disciplina, 2 mestrandos (como ouvintes ativos), 5 professores internos e 2 externos convidados.

No total até o momento participaram da experiência 25 pessoas, professores e alunos com interesse em estudar finanças / custos, logística, empreendedorismo, inovação, gestão do conhecimento, psicodinâmica do trabalho, diversidade cultural, estratégias inovadoras, dentre outros.

Os alunos foram avaliados pela professora responsável ao longo do desenvolvimento da disciplina: pela apresentação dos pressupostos de Metodologias como Dialética, Fenomenologia, Quantificação e Método Hipotético-dedutivo, Arque-genealogia, Cartografia, História e Biologia (1 ponto); pela apresentação e compartilhamento do estudo de um autor de relevância escolhido dentre os sugeridos pelos professores do curso (6 pontos); pela avaliação de um outro autor apresentado por outro colega (1 ponto); e pela apresentação de um artigo publicado nos últimos cinco anos em revistas de alta pontuação (artigos de periódicos indexados na base Scopus ou Web of Science ou qualificados como A1, A2 e no mínimo B1 no Qualis/CAPES Brasil), que teve como principal referência o autor estudado por cada aluno, 2 pontos.

O processo didático e os professores foram avaliados por alunos e professores informalmente ao longo da disciplina, e formalmente no final do segundo ciclo, em 2018.

A experiência e a disciplina estão sendo desenvolvidas num processo em espiral: bases conceituais, apresentação, debates e confronto de ideias, conexão com as temáticas da Administração e dos projetos de teses, avaliação crítica, novas bases conceituais, debates e confronto de ideias, conexão com as temáticas da Administração e dos projetos de tese, avaliação crítica, entre outros, sendo conduzidos pela professora responsável pela disciplina de Epistemologia da Pesquisa em Administração, conforme abordados na seção seguinte, em dois ciclos.

A primeira base conceitual foi sobre Epistemologia - Filosofia da Ciência e o percurso histórico de construção do conhecimento pela humanidade: O mundo antigo (700 a.C. / 250 d.C.); Idade Média /Feudalismo (250 / 1500); Renascença (1500 / 1750); A Era da Revolução (1750 / 1900); Mundo Moderno (1900 / 1950); e Filosofia Contemporânea (1950 - dias atuais).

$\mathrm{Na}$ segunda base conceitual, procurou-se introduzir os alunos nos pressupostos que orientam as metodologias. Em 2017: Dialética, Fenomenologia, Quantificação e o Método Hipotético-dedutivo; e num segundo momento, em 2018, foram acrescentadas e Arquegenealogia, a Cartografia e os Métodos da História / Hermenêutica.

A terceira base conceitual teve como objetivo a utilização das metáforas: Biologia (organismos); Psicologia (prisões psíquicas); Ciências Sociais (cultura); Filosofia (fluxo e transformação); Poder (sistemas políticos); e Política (Dominação), do livro "Imagens da Organização" (Morgan, 2002), texto estudado no mestrado, aceito e entendido por todos os envolvidos como ponto de partida de um diálogo entre a Administração e outras áreas do conhecimento transversais (Silveira, 2005), conforme o Quadro 1. 
Quadro 1: Textos discutidos no PPGAUY em 2017-2018

\begin{tabular}{|c|c|c|}
\hline Áreas do Conhecimento & Turmas & Texto / Autor \\
\hline \multirow{4}{*}{$\begin{array}{l}\text {-Política } \\
\text {-Psicologia } \\
\text {-Ciências Sociais }\end{array}$} & $1 \underline{\mathrm{a}}$. & Mundialização do capital (Chaisnais, 1996). \\
\hline & $1 \mathrm{a}$. & O poder simbólico (Bourdieu, 2003). \\
\hline & 1‥ e 2a. & Modernidade Líquida (Bauman, 2001). \\
\hline & 1‥ e 2a. & Microfísica do Poder (Foucault, 2014). \\
\hline \multirow{5}{*}{$\begin{array}{l}\text {-Biologia } \\
\text {-Filosofia } \\
\text {-Poder } \\
\text {-História }\end{array}$} & 2a. & Micropolítica - Cartografia do desejo (Guattari \& Rolnik, 2007). \\
\hline & 2a. & O Gene Egoísta (Dawkins, 2017). \\
\hline & $2 \mathrm{a}$. & A montanha que devemos conquistar (Mészáros, 2015). \\
\hline & 2a. & Homo Deus (Harari, 2016). \\
\hline & 2a. & Sociedade do Espetáculo (Debord, 1997). \\
\hline
\end{tabular}

Fonte: Elaborado pelos autores (2018).

No total das duas turmas, foram estudados nove livros e sete artigos relacionados ao pensamento de cada autor apresentado na 3 a base conceitual (quatro livros e quatro artigos na 1a turma e oito livros e sete artigos na 2a turma), sendo que dois livros da primeira turma foram substituídos por cinco na segunda turma, por sugestão dos professores convidados que passaram a colaborar com a disciplina.

A validade e confiabilidade da pesquisa foi realizada por meio da avaliação por pares (Merriam, 1998), pela conferência dos pesquisadores para determinar a precisão dos resultados, descrição rica e densa para transmitir os resultados e o uso de auditores externos com expertise na temática do estudo para rever a pesquisa (Mozzato \& Grzybovski, 2011).

\section{ANÁLISE DO PERCURSO REALIZADO}

\section{(2017-Primeiro ciclo)}

Momento a - Contato via e-mail com professores doutores de referência no Brasil, por sua produção acadêmica, solicitando programas da Disciplina de Epistemologia para análise. Esta fase resultou no recebimento de cinco programas de universidades federais. Os programas foram analisados e verificados os pontos convergentes.

Momento $b$ - Diálogo com professores do PPGAUY. Ao dialogar com alguns professores doutores do PPGAUY, na sua maioria com formação nas exatas e quantitativas, com vasta experiência de consultoria empresarial e que valorizam muito a quantificação e a tecnologia; percebeu-se que não houve interesse deles em utilizar uma epistemologia no conteúdo nas teses de doutorado dos orientandos. A fala recorrente era: "somos muito práticos" e calavam, e até brincavam sobre o assunto. Ao se tentar voltar ao tema, ouvia-se de alguns a fala de que uma tese de doutorado era igual a uma dissertação de mestrado.

Momento c - Formatação de um programa inicial para aplicação nas duas primeiras turmas do curso num total de 12 alunos doutorandos. O programa foi dividido em cinco unidades básicas: I - Contextualização; II - Dinâmica da Pesquisa em Ciências Sociais; III - Pressupostos de Análise das Epistemologias; IV - O pensamento Epistemológico da Atualidade; e, V- Avaliação final. 
Momento d - Realização de seminários. A professora responsável pelo programa apresentou para o grupo os conceitos de Filosofia, Epistemologia, Modernidade e Pósmodernidade, para construir com os alunos os pressupostos das grandes metodologias modernas utilizadas nas Ciências Sociais. Os constructos dos pressupostos de orientação das epistemologias, construídos e apresentados pelos alunos nos seminários, tiveram como síntese o Quadro 2.

Quadro 2: Características dos métodos estudados pelos alunos do PPGAUY 2017-2018

\begin{tabular}{|c|l|}
\hline Métodos & \multicolumn{1}{|c|}{ Pressupostos } \\
\hline Dialética & $\begin{array}{l}\text { Modo de produção, totalidade, movimento, contradição, negação, interação, } \\
\text { interdependência, processo histórico, unidade dos opostos, ideologia, complexidade, } \\
\text { reprodução do modelo e alienação. }\end{array}$ \\
\hline Fenomenologia & $\begin{array}{l}\text { Fenômeno, essência, contingência, percepção, interpretação, significados, subjetividade, } \\
\text { suspensão fenomenológica, "aqui e agora", sem a priori e sem tentar fazer referência ao } \\
\text { passado. }\end{array}$ \\
\hline Quantificação & $\begin{array}{l}\text { A verdade é dada, possibilidade de mensuração da verdade, testar diversos tipos de relações } \\
\text { entre conhecimentos, ordenamento, categorização, classificação, amostra representativa, } \\
\text { definição prévia de hipóteses, dedução e obrigatoriedade de tratamento estatístico e/ou } \\
\text { matemático. }\end{array}$ \\
\hline Hipotético- & $\begin{array}{l}\text { Rejeita a indução, observação de um problema, formulação de hipóteses, dedução de } \\
\text { consequências observadas, experimentação, tentativa de falseamento, não existe verdade } \\
\text { absoluta, procura-se evidências empíricas para derrubar ou comprovar as hipóteses e toda } \\
\text { solução para um problema cria novos problemas não solucionados. }\end{array}$ \\
\hline
\end{tabular}

Fonte: Sistematizado pelos autores (2018).

Observou-se que os alunos embora tenham conseguido captar os pressupostos que deveriam orientar os estudos, ainda ficava a insatisfação por obter "o como fazer" próprio do esquema usado nas dissertações de Mestrado do PPGAUY, que caracterizam o tipo de pesquisa como: natureza da pesquisa (quantitativa/ qualitativa), objetivos (com relação à finalidade/ procedimentos) e etapas. Além de um questionário validado para ser aplicado dentro do rigor estatístico, usando a mais avançada tecnologia.

Numa terceira fase da disciplina foram disponibilizados para análise e escolha dos alunos, livros de autores de referência, foram formadas quatro duplas de três alunos para a apresentação de seminários de quatro horas de duração. Foram disponibilizados cerca de dez autores, dos quais foram escolhidos pelos alunos: Bauman, Bourdieu e Chesnais, conforme o Quadro 3.

Quadro 3: Temas trabalhados pelos alunos do PPGAUY 2017-2018

\begin{tabular}{|c|l|}
\hline $\begin{array}{c}\text { Autor / obra } \\
\text { Bauman (2001) - }\end{array}$ & $\begin{array}{l}\text { Quebra das grandes narrativas modernas na pós-modernidade, fragmentação, } \\
\text { individualização e poder e mídias sociais. }\end{array}$ \\
\hline & $\begin{array}{l}\text { Poder e controle nas organizações; os micro-poderes e o Estado; o poder funciona e se } \\
\text { exerce em rede; quem exerce sobre o poder. O poder não existe, existem sim práticas } \\
\text { ou relações de poder; Resistência; Verdade absoluta?; o poder como produtor de } \\
\text { individualidade. O indivíduo é uma produção do poder e do saber. Não há relação de } \\
\text { poder sem constituição de um campo de saber; Discurso; Enunciado; o poder sobre o } \\
\text { corpo do indivíduo; Adestramento; Poder e sociedade. }\end{array}$ \\
\hline $\begin{array}{c}\text { Microfísica do Poder } \\
\text { Bourdieu (2003) - O } \\
\text { poder simbólico }\end{array}$ & $\begin{array}{l}\text { Distinção social, campo, campo de poder, habitus, capital simbólico, espaço social, } \\
\text { violência simbólica e classes. }\end{array}$ \\
\hline
\end{tabular}




\begin{tabular}{|c|l|}
\hline $\begin{array}{c}\text { Chesnais (1996) - } \\
\text { Mundialização do } \\
\text { capital }\end{array}$ & $\begin{array}{l}\text { Serviços, "nova fronteira" para a mundialização do capital; o comércio exterior no quadro } \\
\text { da mundialização: polarização e marginalização; consequências da mobilidade do capital } \\
\text {-Desconexão forçada; o movimento próprio da mundialização financeira; crítica à } \\
\text { natureza dos empréstimos de capital ao terceiro mundo; a internacionalização; } \\
\text { destruição das relações que garantiam estabilidade e crescimento; e, o modo de } \\
\text { produção dominante: }\end{array}$
\end{tabular}

Fonte: Sistematizado pelos autores (2018).

A apresentação dos alunos obedeceu a um roteiro básico em aberto, constando de: introdução, contexto histórico de existência da obra, biografia do autor, conteúdo de uma obra representativa, principais ideias / argumentos / pressupostos defendidos pelo autor, conexão com os estudos organizacionais, questões que o autor estudado levantaria com relação a administração e aos projetos dos alunos, conclusões provisórias, referências e glossário.

Momento e - Análise dos resultados. O poder foi o tema que despertou o maior interesse dos alunos. Tanto o poder formal, como o poder simbólico (Bourdieu, 2003). Entretanto, os doutorandos, em sua maioria originários da área da Administração e da Contabilidade, tiveram grande dificuldade em ler, entender e processar os conteúdos dos livros, valorizando nas apresentações a biografia dos autores.

No momento posterior a disciplina, os orientandos relataram que seus orientadores ignoraram as temáticas trabalhadas na disciplina de Epistemologia da Pesquisa em Administração, e que continuavam com uma visão de mundo positivista/funcionalista. Também foi verificado, por parte de alguns alunos que, por razões "religiosas", tiveram dificuldade em trabalhar os conteúdos de alguns autores considerados ateus.

\section{(2018-Segundo ciclo)}

Momento f - Enriquecimento do processo com o objetivo de obter maior envolvimento dos professores com as premissas da Epistemologia, para a construção das teses de doutorado. Desta forma, entendendo que a disciplina só se consolidaria com a participação de todos os envolvidos - coordenação, professores e alunos -, e que o comprometimento seria resultante de trabalhar conteúdos que fizessem sentidos para os envolvidos; partiu-se para a intensificação do processo de mobilização dos professores. Assim, foram mobilizados professores internos e externos, especialistas em determinadas metodologias e autores, para atuação como orientadores e debatedores em seminários conduzidos pelos alunos, doutorandos da $2 \underline{a}$ turma. A professora responsável pela disciplina intensificou o diálogo individualmente com cada professor de várias áreas do conhecimento trabalhadas no PPGAUY/Stricto Senso da Universidade - Finanças, Logística, Marketing, Gestão de Pessoas, Psicologia, Serviço, Estratégias, dentre outras, explicando a proposta da disciplina e levantando a seguinte questão: "que autor fora da Administração tinha um patamar de conhecimento superior, reconhecido academicamente, capaz de dar pressupostos consistentes para construção de problemáticas relevantes, teses inovadoras e a realização de crítica e discussão dos conteúdos obtidos nas pesquisas sob sua orientação?". 
De imediato obteve-se o comprometimento de três professores/doutores com relação à participação efetiva e imediata no processo, inclusive do coordenador geral dos programas de Mestrado e Doutorado da organização em questão.

Estabeleceu-se, em seguida, a estratégia de chamar professores internos e externos especialistas nos autores escolhidos, e doutorandos que já haviam cursado a disciplina (na primeira turma), para formarem duplas de estudo com os seis novos alunos. Neste segundo ciclo, por sugestão dos professores convidados, foram acrescentadas às metodologias trabalhadas em 2017: a arque-genealogia (Foucault), metodologias relacionadas à História (Harari e Debord), a Cartografia (Guattari) e a Biologia (Dalkins), conforme os pressupostos sintetizados no Quadro 4.

\section{Quadro 4: Síntese dos pressupostos das metodologias adicionados no PPGAUY em 2018}

\begin{tabular}{|c|l|}
\hline $\begin{array}{c}\text { Métodos } \\
\text { genealogia }\end{array}$ & $\begin{array}{l}\text { Entender como os saberes produzem as representações dos sujeitos; negação do refinamento } \\
\text { progressivo do conhecimento; o problema deixa de ser a tradição e o rastro, para ser o recorte e o } \\
\text { limite; organizar o conhecimento definir unidades e descrever relações; estabelecer séries, série de } \\
\text { séries e análise de análise; desligamento do tempo e das cronologias; as coisas não preexistem às } \\
\text { palavras; questiona a totalização dos fenômenos; o discurso do geólogo /historiador passa a ser } \\
\text { ativo na leitura histórica dos fatos; muda a perspectiva de uma “história global” para uma “história } \\
\text { geral"; comunicação: da memorização para a propagação por meio de indivíduos, obras, noções ou } \\
\text { teorias; e contradição. }\end{array}$ \\
\hline $\begin{array}{c}\text { Hermenêutica } \\
\text { (Metodologia } \\
\text { da História) }\end{array}$ & $\begin{array}{l}\text { Interpretação pragmática em busca do conhecimento empírico, interpretação das condições para } \\
\text { obtenço do sentido lógico, interpretação Psicológica para compreensão do sentido empático, e }\end{array}$ \\
\hline Cartografia & $\begin{array}{l}\text { Não coletar apenas os dados, mas produzi-los, não ser apenas o pesquisador, mas o interventor } \\
\text { (sujeito ativo), seguir um processo de autoanálise, utiliza-se do seu corpo como instrumento de } \\
\text { pesquisa, interesse pelas sensações, tensões e vibrações produzidas pelo corpo do entrevistado, } \\
\text { pesquisador arca com a responsabilidade de ser um interventor, captar processos de subjetivação, } \\
\text { não captados por entrevistas, não estabelece regras ou protocolos, inseparabilidade entre conhecer } \\
\text { e fazer, e inseparabilidade entre pesquisar e intervir. }\end{array}$ \\
\hline
\end{tabular}

Fonte: Sistematizado pelos autores (2018).

Momento g - Realização de Seminários. Permaneceu o roteiro básico em aberto, como utilizado em 2017. Foi enfatizada a necessidade de fazer conexão direta entre do texto estudado com as pesquisas da administração.

Neste momento, a contribuição da Biologia foi colocada a partir de Dawkins (2017), com o livro "O Gene Egoísta”, conforme o Quadro 5.

Quadro 5: A contribuição da biologia - Método História abordado no PPGAUY em 2018

\begin{tabular}{|l|l|}
\hline \multicolumn{1}{|c|}{ Principais temas trabalhados } & \multicolumn{1}{|c|}{ Conexão com os estudos organizacionais } \\
\hline -Evolução por meio da seleção natural & -Estudo de potenciais / possíveis cenários \\
-Sobrevivência do mais apto/lei de sobrevivência do estável & $\begin{array}{l}\text { futuros } \\
\text {-Estratégias de sobrevivência das empresas } \\
\text {-Replicador - matriz ou modelo padrão } \\
\text {-Cadeia complexa de vários tipos de blocos moleculares mais } \\
\text { aptos, duradores e adaptados }\end{array}$ \\
-As pessoas, os animais, as bactérias e os vírus são máquinas de & $\begin{array}{l}\text { organizações } \\
\text {-Valorização da ciência e tecnologia }\end{array}$ \\
sobrevivência & -Adoção de políticas altruístas como forma de \\
-O gene é uma unidade suficientemente pequena para durar um & sobrevivência \\
grande número de gerações e ser distribuída sob forma de muitas & -Novos formatos de Gestão de Pessoas e do \\
cópias & $\begin{array}{l}\text { trabalho } \\
\text {-Trabalho vivo \& trabalho morto }\end{array}$ \\
\hline
\end{tabular}

HOLOS, Ano 36, v.6, e8139, 2020 
-Gene - unidade fundamental da seleção natural do interesse próprio que não envelhece e são potencialmente imortais -O egoísmo é o atributo mais geral do gene

-A perpetuação da informação acontece com o gene mais forte engolindo o gene mais fraco

-Os genes se unem tornando-se mais fortes

-O gene altruísta sendo colaborativo tem mais possibilidade de reprodução da informação em outra carga/matéria

-A informação é mais importante do que a matéria

-O magnetismo da cada conjunto de matéria determina o lugar no espaço

-O altruísmo verdadeiro é a maneira mais eficiente de dar o próximo passo na evolução da espécie.
-Novos papéis organizacionais

-Novas competências essenciais para a organização

-Novos perfis de competências profissionais

- Novos perfis de competências sociais

-Gestão do Conhecimento organizacional

-Organizações de Aprendizagem

-E-learning

-Responsabilidade Social

-Precariado

-Ciência e tecnologia.

Fonte: Sistematizado pelos autores (2018).

A apresentação sobre o livro de Dalkins trouxe um impacto inicial para os participantes ao desconstruir paradigmas positivistas/ funcionalistas próprios da Administração. Observou-se a dificuldade por parte dos alunos de transformação do pensamento abstrato em concreto no pequeno, médio e longo prazo, mediante a interpretação de metáforas e analogias do texto com a realidade aparente.

Quanto ao texto de Guattari e Rolnik (2007), sobre a "Microplítica - cartografias do desejo" este trouxe a contribuição da Psicologia para o debate. Os alunos entraram em contato com uma outra visão de mundo, que entende que a subjetividade e a cultura são construídas pelo modo de produção existente, conforme as contribuições levantadas pelos alunos no Quadro 6.

Quadro 6: A contribuição da Psicologia - Método Cartografia abordado no PPGAUY em 2018

\begin{tabular}{|c|c|}
\hline Principais temas trabalhados & $\begin{array}{c}\text { Conexão com os estudos } \\
\text { organizacionais }\end{array}$ \\
\hline $\begin{array}{l}\text { - O modo de produção predominante como construtor, modelador e } \\
\text { controlador da subjetividade e da cultura } \\
\text {-A cultura é reacionária } \\
\text {-As crianças são seres não dominantes, enquanto estão longe do } \\
\text { processo de subjetividade capitalista } \\
\text {-A produção de subjetividade é mais importante do que qualquer } \\
\text { produção econômica } \\
\text {-Os sistemas terapêuticos e das universidades, quando considerados } \\
\text { simples depositários ou canais de transmissão, reforçam a } \\
\text { subjetividade do modo de produção dominante } \\
\text {-Os indivíduos são produtos da massa e são terminais } \\
\text {-Os movimentos sociais são tentativas de produzir subjetividade } \\
\text { original e singular; } \\
\text {-A singularização acaba com a interiorização dos valores capitalistas } \\
\text {-Construção de uma sociedade organizada, não utópica, com modos } \\
\text { de subjetivação diferentes das bases capitalistas. }\end{array}$ & $\begin{array}{l}\text {-Pesquisas relacionadas à gestão de } \\
\text { pessoas; } \\
\text {-Pesquisa sobre diversidade; } \\
\text {-Pesquisa sobre entrincheiramento; } \\
\text {-Todas as pesquisas que possam ser } \\
\text { desenvolvida na perspectiva da } \\
\text { observação e intervenção. } \\
\text {-Pesquisas sobre Marketing e } \\
\text { comportamento do consumidor. } \\
\text {-Subjetividade } \\
\text {-Cultura organizacional social } \\
\text {-Uso de mídias sociais } \\
\text {-Percepção do Cliente e do cidadão } \\
\text { - Organizações não governamentais } \\
\text {-Educação corporativa. }\end{array}$ \\
\hline
\end{tabular}

Fonte: Sistematizado pelos autores (2018).

Com o seminário sobre Guattari e Rolnik as teorias clássicas da psicologia foram confrontadas. Surge como principal paradoxo: o livre arbítrio - nós dirigimos conscientemente nossos atos ou eles são regidos por outras forças?

Já em Bauman (2001), no livro "Modernidade Líquida", este trouxe à reflexão dos alunos a perspectiva de que a liquidez da sociedade pós-moderna faz com que ela seja melhor adaptada HOLOS, Ano 36, v.6, e8139, 2020 
aos meios, ocupe e desocupe um ambiente com a mesma facilidade para rapidamente adquirir uma nova forma, mantendo um constante ciclo de quebra do status quo em que os objetos não duráveis tomam conta e a durabilidade das coisas (ideias, valores, crenças, culturas, hábitos) já não são mais valorizados, conforme o Quadro 7.

Quadro 7: A contribuição da Sociologia e Filosofia - Método Dialética no percurso do PPGAUY 2017-2018

\begin{tabular}{|l|l|}
\hline \multicolumn{1}{|c|}{ Principais temas trabalhados } & \multicolumn{1}{|c|}{ Conexão com os estudos organizacionais } \\
\hline -Globalização & -Comprometimento/vínculo organizacional \\
-Modernidade & -Terceirização \\
-Pós-modernidade & -Sindicatos/classes trabalhadoras \\
-Consumismo & -Precariado. \\
-Moralidade & \\
-Fragmentação & \\
-Descentralização & \\
-Mundo líquido & \\
-Redes sociais & \\
-Emancipação & \\
-Individualidade & \\
-Tempo/Espaço & \\
-Trabalho Comunidade. & \\
\hline
\end{tabular}

Fonte: Sistematizado pelos autores (2018)

O livro de Bauman mostrou a quebra dos grandes discursos da modernidade, vínculos humanos e ações sociais acarretando a imprevisibilidade de obtenção de certezas na pesquisa acadêmica.

A partir Harari (2016), com a obra "Homo Deus", entrou-se em contato com a Hermenêutica, enquanto interpretação da história, conforme as contribuições levantadas pelos alunos e descritas no Quadro 8.

Quadro 8: A contribuição da História / Hermenêutica - Método História no PPGAUY em 2017-2018

\begin{tabular}{|c|c|}
\hline Principais temas trabalhados & $\begin{array}{c}\text { Conexão com os estudos } \\
\text { organizacionais }\end{array}$ \\
\hline $\begin{array}{l}\text {-Impossibilidade de predizer o futuro } \\
\text {-Com o crescimento da Inteligência Artificial há um potencial dela se tornar } \\
\text { dominante na terra ou além da terra e trazer impactos para o Homo Sapiens } \\
\text {-Os homens serão substituídos na maioria dos trabalhos que existem hoje } \\
\text {-Novas profissões irão surgir, mas nem todos conseguirão se reinventar e se } \\
\text { qualificar para essas funções } \\
\text {-Uma nova classe de pessoas surgirá: a dos inúteis, que não serão empregáveis } \\
\text {-Todo animal, inclusive o Homo Sapiens, é um conjunto de algoritmos orgânicos } \\
\text { moldados pela seleção natural através de milhões de anos de evolução } \\
\text {-Os próximos alvos serão a imortalidade, a felicidade e a divindade } \\
\text { - A felicidade poderá ser comprada através de pílulas ou engenharia genética } \\
\text {-A felicidade é individual, e o que faz cada individuo feliz, varia imensamente, } \\
\text { ações coletivas não provocam a felicidade coletiva } \\
\text {-A morte será uma mera falha técnica, os humanos serão amortais } \\
\text { - A tecnologia entregará muito mais poderes do que os deuses antigos } \\
\text {-Transformação do homem em sua própria divindade } \\
\text { - Não é possível pisar nos freios e impedir que tudo isso aconteça, a pesquisa } \\
\text { científica e a tecnologia se desenvolvem de forma tão rápida, que se torna cada }\end{array}$ & $\begin{array}{l}\text {-Cenários e tendências } \\
\text {-Dataismo } \\
\text {-Gestão descentralizada } \\
\text {-Novas profissões } \\
\text {-Novos } \\
\text { organizacionais } \\
\text { - Pessoas } \\
\text { empregáveis/ inúteis } \\
\text { - Humanos como máquinas } \\
\text { de processar dados } \\
\text {-Organismos } \\
\text { algoritmos } \\
\text {-Papel dos grupos } \\
\text {-Interação entre humanos } \\
\text { e máquinas } \\
\text {-Inteligência Artificial } \\
\text { - } \\
\text { Tecnologia/Processamento } \\
\text { de dados }\end{array}$ \\
\hline
\end{tabular}


vez mais difícil saber o que está acontecendo. E assim, "como ninguém compreende o sistema como um todo, ninguém pode fazê-lo parar

-O paradoxo do conhecimento (aumenta o conhecimento e compreendemos menos o mundo);

-Paradoxo: futuro do passado, baseado nas ideias e esperanças que dominaram o mundo nos últimos 300 anos x futuro real, baseado em ideias e esperanças do séc. XXI

-Tentar entender quais foram os desafios da humanidade até agora, e, imaginar a partir do presente, quais serão os desafios futuros.

-Não profetiza, aponta tendências embasadas pelas ciências.
-Valores

religiosos influindo na subjetividade cultura

Fonte: Sistematizado pelos autores (2018).

Entender e aprender com a história passada e presente nos permitiria compreender o presente e apresentar uma possibilidade de futura visão da sociedade? Esta foi a principal reflexão propiciada pelo texto.

Com Mészáros (2015), em "A montanha que devemos conquistar", apresentou-se uma reflexão dos papeis do Estado e o questionamento de sua atuação enquanto viabilizador do modo de produção existente. A Filosofia apresenta a realidade na forma mais ampla, questionando o sistema político em sua totalidade, conforme demonstrado pela contribuição dos alunos no Quadro 9.

Quadro 9: A contribuição da Filosofia - Método Dialética Materialista no PPGAUY em 2017-2018

\begin{tabular}{|l|l|}
\hline \multicolumn{1}{|c|}{ Principais temas trabalhados } & \multicolumn{1}{|c|}{ Conexão com os estudos organizacionais } \\
\hline -Paradigma histórico & -Gestão Pública \\
-O papel do Estado na ordem do capital - lei dos mais fortes: & -Políticas Sociais \\
-Crise estrutural do capital: & -Comportamento de consumo por \\
-Interligação dos pilares & "status". \\
-Estado protetor da hierarquia social & -Escolha na decisão da profissão. \\
-Anarquia utópica sem lei & -Exploração dos funcionários e da \\
-Falsa ideologia do dever do estado: & comunidade em busca do lucro \\
-Classe trabalhadora x capital & -Responsabilidade Social. \\
-Fenecimento do Estado na concepção tradicional & -Gestão de custos apenas buscando a \\
& maximização do lucro. \\
\hline
\end{tabular}

Fonte: Sistematizado pelos autores (2018)

Já a contribuição da Psicologia, no olhar de Foucault (2014) em "Microfísica do Poder", remeteu para o interior das organizações, sobre o poder como lócus, fixidez e estabilização de um sujeito sobre os outros; Michel Foucault desconstrói esse conceito e apresenta-o como fluido, disperso, relacional e que contém não apenas repressões, mas também resistências no seu interior. Nesse momento, a grande questão suscitada foi: quais relações estão presentes nas práticas organizacionais diárias onde o nosso fazer toma forma de poder? As contribuições levantadas pelos alunos, conforme o Quadro 10 buscaram identificar os sujeitos atuando uns sobre os outros, suas produções de verdades, subjetividades, lutas e consequências no ambiente organizacional.

Quadro 10: A contribuição da Psicologia - Método Arque-genealogia no PPGAUY em 2017-2018 Principais temas trabalhados

Conexão com os estudos organizacionais 
-Os poderes se exercem em níveis variados e em pontos diferentes da rede social e neste complexo os micro-poderes existem integrados ou não ao Estado

-O poder funciona e se exerce em rede

-Os indivíduos, em suas malhas, exercem o poder e sofrem sua ação. Cada um de nós é, no fundo, titular de um certo poder

-O poder não existe; existem sim práticas ou relações de poder

-Onde há poder há resistência, não existe propriamente o lugar de resistência, mas pontos móveis e transitórios que também se distribuem por toda a estrutura social

-Não existe uma verdade absoluta, somente diferentes verdades sobre a realidade em diferentes momentos - verdades que atendem às necessidades do poder

-O poder é produtor de individualidade

-O indivíduo é uma produção do poder e do saber

-Não há relação de poder sem constituição de um campo de saber, como também reciprocamente, todo saber constitui novas relações de poder -O poder se gera e materializa em uma gama extensa de relações pessoais desde as quais se leva a constituir estruturas impessoais

-O poder volta-se para o corpo do indivíduo, não com a intenção de reprimi-lo, mas de adestrá-lo

-O poder e saber estão intimamente ligados

- O poder continua centralizado nas mãos de uma pequena parte da sociedade, que se utiliza de instituições e organismos para manipular, persuadir e neutralizar a grande massa para a manutenção de mecanismos que impossibilite a sua ascensão social.
-Análise de ferramentas de gestão (qualidade total, times de trabalho) -Poder

-Estratégia empresarial

-Diversidade

-Controle

-Tecnologia de informação

(panóptico)

-Processos organizacionais,

-Discurso de grandes corporações

-Governança empresarial

-Biopolítica

Fonte: Sistematizado pelos autores (2018).

Debord (1997), em "Sociedade do Espetáculo", trouxe à reflexão como o fetichismo da mercadoria é marcante no cotidiano da sociedade, como o tempo e o espaço perderam sua configuração "normal" e se tornaram virtuais, como as pessoas perderam a autenticidade nas suas formas de viver, pois a vida se tornou uma representação e pura ilusão e, como as relações sociais passaram a ser mediadas por imagens, conforme o Quadro 11.

Quadro 11: A contribuição da Comunicação Social - Método Dialética Materialista no PPGAUY em 2018

\begin{tabular}{|l|l|}
\hline \multicolumn{1}{|c|}{ Principais temas trabalhados } & $\begin{array}{c}\text { Conexão com os estudos } \\
\text { organizacionais }\end{array}$ \\
\hline -Realidade x espetáculo & -Marketing \\
-Característica positiva indiscutível & \\
-Aceitação passiva & \\
-O êxito do sistema econômico da separação significa a proletarização do mundo \\
-Fetichismo da mercadoria \\
-A mercadoria aparece como potência vindo para ocupar realmente a vida social \\
-No capitalismo avançado a ideia de mercadoria sofre mudanças radicais de \\
objeto material para elemento intangível \\
- Concepção Proletária \\
-O proletariado como sujeito e como representação \\
-Trabalhadores dialéticos, traduzindo seu pensamento na prática
\end{tabular}

Fonte: Sistematizado pelos autores (2018).

O texto apresentado, apoiado por vídeos de propagandas atuais, mostrou como a subjetividade não é somente construída pelo modo de produção, mas como o desejo latente e inconsciente, é apropriado pelo marketing em benefício do mercado. 
Momento $\mathrm{h}$ - Avaliação e análise dos resultados. Os alunos das três turmas tiveram excelente aproveitamento, tendo obtido notas nove (11 alunos) e 10 (sete alunos). 0 que significa o cumprimento com êxito de todas as etapas de avaliação. Os indicadores de avaliação da participação dos alunos foram: atenção na exposição, envolvimento no processo de aprendizagem e compreensão dos conceitos, utilização de conhecimentos teóricos para apoiar argumentos, capacidade de estabelecer relações causais, capacidade de contextualização dos conceitos, e capacidade de expressão oral e escrita.

A avaliação final da disciplina, feita em ferramenta virtual, contou com a participação dos 18 alunos do doutorado das três turmas e um aluno de mestrado, que participou como ouvinte. Essa avaliação foi realizada por meio de entrevista estruturada (Merriam, 1998) com oito afirmativas e uma escala de quatro pontos variando de "não concordo" a "concordo muito". e por entrevista semiestrutura (Godoy, 1995), guiada por quatro questões. Nesse sentido, a maioria dos alunos considerou a metodologia, as referências, a atuação da professora, o comprometimento dos alunos, o ambiente físico, o processo de avaliação, e a importância do estudo da Epistemologia como pontos altos da experiência.

Nas entrevistas semiestruturadas, 12 alunos expressaram suas percepções sobre os autores estudados, a aproximação desses autores com as temáticas de suas propostas de teses e sugestões para a melhoria da disciplina de Epistemologia da Pesquisa em Administração, quando se verificou que: os alunos demonstraram interesse pelo conteúdo da disciplina e ficaram sensibilizados para a utilização da Epistemologia em suas teses de doutorado. As sugestões de melhorias focaram nas referências, sobre a escolha de autores para a disciplina mais próximos das temáticas das propostas de teses, tais como Bourdieu, Bauman, Vygotsky, Bachelard, Morgan e Foucault; embora itens como o objetivo da disciplina, a atuação da docente, o ambiente físico, os critérios de avaliação do desempenho dos alunos e o diálogo com o orientador, também tenham sido colocados em avaliação. Pelas entrevistas, a principal dificuldade está no diálogo com professores orientadores e na busca de uma epistemologia que seja adequada para cada tema de tese em construção.

Como sugestão sistematizou-se: o aumento da carga horária da disciplina, dividir a disciplina em duas (Epistemologia da Pesquisa em Administração I - Métodos e II - Aplicação dos Métodos por autores de referência), manter os professores convidados; e a disponibilização das obras que serão trabalhadas com antecedência. Em complemento, as falas dos professores convidados, registradas durante a disciplina pela professora que conduziu o processo educacional, sinalizam para a validade do caminho adotado na construção da disciplina, que em seu prosseguimento deverá incorporar, após análise, novos procedimentos e novos conteúdos, pois são os seres do objeto que sinalizarão os caminhos para conhecê-lo e não a nossa razão (Ferraz et al., 2018), que no processo de construção da experiência, está sendo considerada um estágio intermediário (Bachelard, 1996). 


\section{CONSIDERAÇÕES PROVISÓRIAS}

Os resultados apontaram para o enriquecimento da disciplina ao longo de um ano e o engajamento dos alunos e aproximação de professores na construção de conteúdos relevantes para a disciplina. Verificou-se, no entanto, ainda resistência de alguns professores orientadores para utilização da Filosofia da Ciência na construção das teses de doutorado dos alunos.

A principal dificuldade do grupo, incluindo os professores, seria sair do paradigma teórico funcionalista, que não questiona o sistema e que entende a Educação como um instrumento de inserção na realidade existente baseada no mercado, sem questionar que a exclusão social é fruto do sistema. Fica a grande questão: é possível transformar a realidade em benefício do conjunto da sociedade pela Administração?

As limitações do estudo residem na medida em que o relato tenta reunir as intencionalidades vivas, pois ele se inscreve no movimento das intencionalidades próprias dos autores-interpretadores. Portanto, toda tentativa de decifração da realidade da experiência em curso, permanece, em tese, fixada numa perspectiva, nas iniciativas das subjetividades dos autores que a constroem. Além disso, ainda existem lacunas associadas à participação da coordenação do PPGAUY nesse processo, pois não foi ouvida; ao envolvimento de outros docentes do programa na disciplina de Epistemologia da Pesquisa em Administração; à criação de uma linha ou grupo de pesquisa que consolide a conexão entre epistemologia, metodologias e textos contemporâneos de áreas do conhecimento com temáticas transversais, para as teses dos alunos; e a utilização de outros autores, reconhecidos do ponto de vista acadêmico, tais como Vygotsky, Bachelard e Morgan, sugeridos pelos próprios alunos.

As sugestões de estudos futuros estão sobre a continuidade desse relato, que tem caráter provisório, buscando-se o aprofundamento da experiência por meio de entrevistas em profundidade com os atores do processo - professores internos e externos, alunos e coordenação do PPGAUY, bem como, estudos comparativos com outros programas de pós-graduação em administração novos ou maduros.

\section{AGRACEDIMENTOS}

O presente trabalho foi realizado com apoio da Coordenação de Aperfeiçoamento de Pessoal de Nível Superior - Brasil (CAPES) - Código de financiamento 001.

\section{REFERÊNCIAS}

Bachelard, G. (1996). A formação do espírito científico. Rio de janeiro: Contraponto.

Bourdieu, P. (2003). O poder simbólico. 6a. Ed. Rio de Janeiro: Bertrand Brasil.

Burrell, G., \& Morgan, G. (2017). Sociological paradigms and organisational analysis: Elements of the sociology of corporate life. Routledge. 
Burrell, G., \& Morgan, G. (1979). Sociological paradigms and organisational analysis: Elements of the sociology of corporate life. Vermont: Ashgate.

Brasil. (2018). Ministério da Educação. Coordenação de Aperfeiçoamento de Pessoal de Nível Superior. Plataforma Sucupira. Brasília. Recuperado em 10 novembro, 2018, de http://www.capes.gov.br/avaliacao/plataforma-sucupira.

Bruyne, P. de, Herman, J., \& Schoutheete, M. de. (1991). Dinâmica da pesquisa em ciências sociais: os polos da prática metodológica. 5a . ed. Rio de Janeiro: F. Alves.

Cellard, A. (2012). A análise documental. In Poupart, J. A pesquisa qualitativa: enfoques epistemológicos e metodológicos. Petrópolis: Vozes.

Costa, F. D. (2011). Mensuração e desenvolvimento de escalas: aplicações em administração. Rio de Janeiro: Ciência Moderna.

Chesnais, F. (1996). A mundialização do capital. São Paulo: Xamã.

Creswell, J. W. (2002). Educational research: Planning, conducting, and evaluating quantitative. Upper Saddle River, NJ: Prentice Hall.

Dana, L. P., \& Dumez, H. (2015). Qualitative research revisited: epistemology of a comprehensive approach. International Journal of Entrepreneurship and Small Business, 26(2), 154-170. Doi: 10.1504/IJESB.2015.071822.

Dawkins, R. (2017). O gene egoísta. Editora Companhia das Letras.

Debord, G. (1997). A sociedade do espetáculo. Rio de Janeiro: Contraponto Editora.

Denzin, N. K., \& Lincoln, Y. S. (Eds.). (2011). The SAGE handbook of qualitative research. Sage.

Ferraz, D. L. D. S., Chaves, R. H. S., \& Ferraz, J. D. M. (2018). Para além da epistemologia: reflexões necessárias para o desenvolvimento do conhecimento. REAd. Revista Eletrônica de Administração (Porto Alegre), 24(2), 1-30. Doi: 10.1590/1413-2311.204. 80474.

Foucault, M. (2014). Microfísica do poder. 28a. ed. São Paulo: Paz e Terra.

Flick, U. (2004). Uma introdução à Pesquisa Qualitativa. São Paulo: Artmed.

Godoy, A. S. (1995). Introdução à pesquisa qualitativa e suas possibilidades. Revista de Administração de Empresas, 35(2), 57-63.

Guattari, F., \& Rolnik, S. (2007). Micropolítica: cartografias do desejo. Petrópolis: Vozes.

Habermas, J. (2012). Teoria do agir comunicativo: Sobre a crítica da razão funcionalista. Trad. Flávio Beno Siebeneichler. WMF Martins Fontes.

Harari, Y. N. (2016). Homo Deus: uma breve história do amanhã. Trad. Paulo Geiger. São Paulo: CIA das Letras. 
Lukács, G. (2015). Para uma ontologia do ser social 1. Boitempo Editorial.

Meister, J. (1999). Educação corporativa: a gestão do capital intelectual através das universidades corporativas. São Paulo: Makron Books.

Mendoza, J. M. (2018). Epistemología de la administración: objeto, estatuto, desarrollo disciplinar y método. Revista científica Pensamiento y Gestión, (45).

Merriam, S. (1998). Qualitative Research and Case Study Applications in Education. San Francisco: Jossey-Bass.

Mészáros, I. (2015). A montanha que devemos conquistar: reflexões acerca do Estado. Boitempo Editorial.

Morgan, G. (2002). Imagens da Organização. São Paulo: Atlas.

Mozzato, A. R., \& Grzybovski, D. (2011). Análise de conteúdo como técnica de análise de dados qualitativos no campo da administração: potencial e desafios. Revista de Administração Contemporânea, 15(4), 731-747.

Paula, A. P. P. de. (2016). Para além dos paradigmas nos Estudos Organizacionais: o Círculo das Matrizes Epistêmicas. Cadernos EBAPE. BR, 14(1), 24-46.

Putnam, L. L., Fairhurst, G. T., \& Banghart, S. (2016). Contradictions, dialectics, and paradoxes in organizations: A constitutive approach. The Academy of Management Annals, 10(1), 65-171. Doi: 10.1080/19416520.2016.1162421.

Rocha, L. C. S., Araújo, G. E. F. de, \& Marques, R. O. (2012). Abordagens Epistemológicas nas Pesquisas em Administração: Uma Análise nas Dissertações de um Programa de PósGraduação no Nordeste Brasileiro. HOLOS, 4, 126-147. Doi: 10.15628/holos.2012.976.

Semprebom, E., Freitas, A., \& Augusto, P. O. M. (2013). Etnografia. In Takahashi, A. R. W. (Org.) Pesquisa Qualitativa em Administração - Fundamentos, métodos e usos no Brasil. São Paulo: Atlas.

Serva, M. (2017). Epistemology of Administration in Brazil: State of the Art. Cadernos EBAPE. $B R, 15(4), 741-750$.

Silveira, R. A. da. (2005). Michel Foucault: poder e análise das organizações. Rio de Janeiro: Editora FGV.

Surak, K. (2017). Rupture and Rhythm: A Phenomenology of National Experiences. Sociological Theory, 35(4), 312-333.

Tesch, R. (2013). Qualitative Types: Analysis Typ. Routledge.

Van Seggelen-Damen, I. C., \& Romme, A. G. L. (2014). Reflective questioning in management education: Lessons from supervising thesis projects. SAGE Open, 4(2), 2158244014539167. 
Vygotsky, L. S. (2001). A construção do pensamento e da linguagem. Trad. Paulo Bezerra. São Paulo: Martins Fontes Editora Ltda.

Zygmunt, B. (2001). Modernidade líquida. Rio de Janeiro: Zahar.

\section{COMO CITAR ESTE ARTIGO:}

Brito, L. M. P., Castro, A. B. C. de, Sousa, J. C. de, Figueiró, R. de A. (2020). Por um caminho para o ensino da epistemologia na administração - uma construção compartilhada. Holos. 36(6), 1-20.

SOBRE OS AUTORES (Não preencher no arquivo em Word. Inserir as informações no sistema da revista no ato da submissão na área dos METADADOS)

\section{LYDIA MARIA PINTO BRITO}

Doutora em Educação e mestre em sociologia pela Universidade Federal do Ceará. Graduada em Serviço Social pela Universidade Estadual do Ceará. E-mail: lydiampbrito@yahoo.com.br

ORCID ID: http://orcid.org/0000-0003-1514-9476

\section{AHIRAM BRUNNI CARTAXO DE CASTRO}

Doutorando em Administração e Mestre em Administração pela Universidade Potiguar (UNP, RN), especialista em Extensão Rural para o Desenvolvimento Sustentável pela Universidade Federal Rural do Semi-Árido (UFERSA, RN) e em Gestão de Pessoas pela Universidade Federal do Rio Grande do Norte (UFRN, RN). Graduado em Administração pela Universidade Potiguar (UNP, RN). Administrador no Instituto Federal de Educação, Ciência e Tecnologia do Rio Grande do Norte (IFRN, RN). E-mail: brunnicastro@ hotmail.com ORCID ID: http://orcid.org/0000-0001-5952-953X

\section{JULIANA CARVALHO DE SOUSA}

Doutoranda em Administração pela Universidade Potiguar. Mestre em Administração pela Universidade Estadual do Ceará e graduada em Administração pela Universidade Federal Rural do Semi-Árido. E-mail: juli.cs1009@gmail.com ORCID ID: http://orcid.org/0000-0002-0388-3959

\section{RAFAEL DE ALBUQUERQUE FIGUEIRÓ}

Doutor, mestre e graduado em Psicologia pela Universidade Federal do Rio Grande do Norte. E-mail: figueiroz@hotmail.com

ORCID ID: http://orcid.org/0000-0003-0671-738X

Editor(a) Responsável: Francinaide de Lima Silva Nascimento Pareceristas Ad Hoc: RICHARD ARAÚJO E HENRIQUE LUIZ CAPRONI NETO

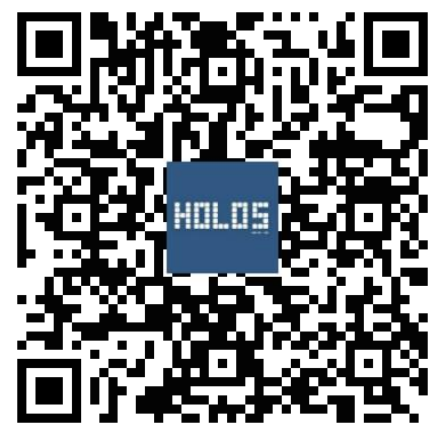


